\title{
DIE BETEKENIS VAN DIE TEOLOGIESE SKOOL VIR ONS KERKLIKE LEWE.
}

Bostaande onderwerp kan die beste belig word deur te wys op die grondslag, doel, noodsaaklikheid en arbeid van die Skool van ons Kerk.

I(a) Die grondslag is van huis uit Gereformeerd. Dieselfde bodem dus waarop die Kerk van die Skool gefondeer is. Nader verklaar, beteken dit, dat ons Teologiese Skool staan op die beginsels van die Bybel, soos dit in die drie Formuliere van Enigheid vertolk en vasgelê is deur die Nasionale Sinode van Dordrecht, in die jaar 1619.

Blykens vrae in die jaar 1868 (dus kort vóór die stigting van die Teol. Skool) deur 'n destydse "Synodale Commissie" aan aspirant proponente gestel, was die staundpunt reeds Gereformeerd. „De praeses (Ds. D. Postma snr.) doet de volgende gewetensvragen aan de Examinandi: 1e omtrent hun geloof in God, volgens art. 1 der Nederlandsche Belijdenis des Geloofs. 2e omtrent hun geloof aangaande de Openbaring Gods, volgens art. 2 dier belijdenis.

3e Aangaande de goddelikheid der Heilige Schrift, volgens art. 7 dier belijdenis.

4e Over hun persoonlijk geloof in Jezus Christus als hunnen volkomen Zaligmaker.

En, 5e Aangaande hunne roeping tot de Evangeliebediening, of zij door de liefde van Christus, en de begeerte om zielen voor Hem en Zijn Koninkrijk te winnen, gedreven worden. Op al deze vragen wordt door de Examinandi bevestigend geantwoord." Dit is vandag, na 75 jaar, nog die grondslag van ons Teol. Skool.

b) Die doel van die stigting? Hierop het wyle prof. Cachet in sy feesrede van 1889 geantwoord: „Ons doel was tweevoudig: allereerst, wilden wij dienaren voor de kerk vormen, maar tegelijkertijd wenschten wij algemeen nuttig te zijn . ..." Hierdie doel kon natuurlik nooit beter gedien word as deur 'n Skool nie. 'n Eie Skool! 'n Teologiese Skool, waar onderwys in die heilige Godgeleerdheid verskaf sou word deur manne van ongerepte regsinnigheid, wetenskaplike bekwaamheid en vrome wandel. Dat so 'n skool noodgedwonge maar 'n klein begin sou hê, was vir die stigters geen beswaar nie. Dát hulle om die „klein begin” en om so 'n eie, aparte inrigting deur vyande beskimp sou word, en selfs as "agterblywers" en vir ,anti-wetenskaplik” gebrandmerk sou word,-dit was vir hulie ook geen verrassing nie. Dit het hulle ook nie van strook gebring nie. Volkome bewus van, en ten volle op hoogte met die opvoedende krag en vormende waarde van 'n eie Teologiese Skool, het ons vaders in 1869 tot daadwerklike Skoolstigting oorgegaan te Burgersdorp. 
c) Oor die noodsaaklikheid van 'n eie opleiding deur die Kerk vir die Kerk, hoef nie veel gesê te word nie. Nie, omdat hierdie punt van minder belang sou wees nie, maar omdat die geskiedenis van die Gereformeerde Kerke sowel in Europa as in Amerika al kant en klaar uitspraak gedaan het ten gunste van 'n eie kerklike opleiding. Vandaar dat ons Kerkorde die saak oor onderwys volstrek nie links laat lê het nie. Artikels 18-20 gee rigting aan vir die kerk in dié verband. Hiervolgens lê dit wel deeglik op die weg van die geïnstitueerde .kerk om te sorg vir 'n eie Teologiese Skool. „De Gereformeerde Kerken hebben altijd cene behoorlijke opleiding van Evangeliedienaren voorgestaan, hebben altijd bij vroomheid en rechtzinnigheid ook bekwaamheid en kennis geëischt. Dit verlangden ook wij in dit land, en uit die behoefte werd de School geboren." ... aldus prof. Cachet. Die geskiedenis van die Nederlands-Hervormde Kerkgenootskap het verder afdoende bewys gelewer, dat sodra die regsinnigheid uit die opleiding van toekomstige predikante verdwyn, die fondamente van die Kerk geskud word, die Kerk ontrou word aan sy goddelike roeping; die kerk begin deformeer en kragteloos word in die stryd teen die sonde en vir die geopenbaarde waarheid. Menslikerwys gespreek, kán die Kerk net dán regsinnig bly, as hy o.m. streng toesig hou oor die opleiding van die toekomstige evangeliedienaars. Die Skool is daar om die Kerk se welsyn ... om onontbeerlike hulpdiens vir die Kerk te verrig ... om mense van God te vorm, ... om geestelike pyle te slyp, waarmee die vyand se aanvalle kan afgeweer word. Die Skool is noodsaaklik! In die Skool lê die toekoms van die Kerk! Daarom het ons vaders die Skool genoem: „die Siel van die Kerk."

11 (a) En nou die arbeid van die Teologiese Skool gedurende 'n driekwarteeu? Eers te Burgersdorp, en sinds 1905 te Potchefstroom? Het die genoemde inrigting iets beteken vir die arbeid en welsyn van die Gereformeerde Kerk in Suid-Afrika? Vir die Kerk, wat die Skool in die geloof onder biddend opsien tot God, opgerig en tot hede toe staande gehou het? Staande gehou het, soms met groot opofferinge, sowel van die kant van professore en studente as van diê van die gemeentes! Vóór ek op die vraag ja of nee antwoord, laat my eers nader inspeksie hou.

(b) Wat die genoemde grondslag van die inrigting betref-die die Christelike en nasionale.-Omdat dit Bybels, konfessioneel-bybels is, daarom is dit goed; sedelik-goed ook voor God; kostelike goud, en besit dit reeds as sodanig geweldige betekenis vir die Kerk. Gedurende sy 75jarige bestaan het die Skool hierdie rotsvaste bodem van Gods Woord, volgens my wete, nie eenmaal verlaat nie. Ondanks vroeëre, latere en die allerlaaste swaar tye en oorloë, wat die inrigting geskud en getoets het, selfs deur bloedoffers te verg.... des ondanks het dit sy gesonde 
nasionale standpunt nie verloën nie, maar wel gehandhaaf sonder om apologie daarvoor te maak. Direk en indirek het hierdie beginseltrou die gemeentes self ten goede gekom. Hierdie nasionale standvastigheid van die Skool moet egter as 'n vrug van sy Gereformeerd-Christelike fondament aangemerk word. Ook hiervan was geen afwyking nie, nóg deur kuratore, professore of studente! Nooit het die Kerk rede gehad om 'n teologiese professor, dosent of teologiese student uit oorsaak van onregsinnigheid in die leer, onder verhoor te moet neem nie.

Inteendeel, daar was en is tot vandăg toe baie stof vir Kerk en Skool om die Here te dank vir die gesonde konfessionele grondslag, waarop die inrigting nog staan en stry vir die Geloof, wat eenmaal aan die heiliges oorgelewer is. Met groot dankbaarheid mag dus verklaar word: dic Gereformeerd-bybelse standpunt van ons Teologiese Skool is na 'n driekwarteeu nog kerngesond, soos wat die stigters dit destyds gewil het. En, -wie sal die betekenis van hierdie enkele feit vir die syn en welsyn van ons kerk na waarde kan takseer! Is twyfel, onsekerheid of dwaalleer altyd en oral 'n ramp vir die soekende siel en die strydende kerk,--daarenteen is belydenisvastheid en koersbewustheid steeds 'n seen vir die vermoeide reisiger na die ewigheid. En vir hierdie ramp of seen is Skool en Kerk tot 'n baie groot mate verantwoordelik, alnaar hulle die heilige beginsels van Gods Woord óf verloën of standvastiglik geleer het in die Skool, verkondig het van die kansels af, en bely het in die daaglikse lewe.

Die Kerk kan sy Skool, na soveel jare van arbeid dus net lof toeswaai vir die tot-hier-toe aan die dag gelegde beginseltrou!

En, laat ons daaraan dink, daardie Skool bestaan uit vlees en bloed; uit professore en studente, mense van gelyke beweginge as u en ek.... Veral noem ek ons teologiese professore, van wie sommige al vir soveel -jare agtereen trou bly staan het op dieselfde beproefde grondslag! Die Kerk moet hierdie feit, by 'n geleentheid soos hierdie, pertinent uitspreek, en selfs op die een of ander tasbare wyse, dankbaar waardeer. Want die manne se betekenis, was en is vir ons kerklike lewe van onskatbare waarde, wat in terme van geld nie bereken kan word nie, maar namaals vergeld sal word deur die Koning van die Kerk.

Andersyds is deur hulle houding aan ons Gereformeerde Kerk hier te lande die skade en ellende, wat gewoonlik deur beginselversaking van onregsinnige professore of predikante veroorsaak word-nog bespaar geword.

Gesien die afval in ons tyd, en ons vermeerderde professore- en predikantetal, moet hierdie konfessie-getrouheid as van die allergrootste betekenis geskat word, en tewens as 'n besondere guns van God oor ons Kerk en kerklike lewe aangemerk word. 
Naas en onder God moet hierdie verskynsel onder andere toegeskrywe word aan ons professore asook aan die konfessionele karakter van die propedeutiese studies aan die P.U.K. vir C.H.O. 'n Voorreg, wat ons kerk bokant ander kerke geniet, en wat ons beslis beny word deur ander kweekskole. Hiervoor 'n eresaluut aan die veterane van die P.U.K.!!

(c) Wat die doel nogeens betref,-—naamlik opleiding, vorming van bedienaars van die Woord vir die Kerk van Christus. Net soos sy grondslag, só het die Skool ook sy doel nooit·losgelaat nie! Met 'n goeie gewete kan die Kuratorium verklaar, dat dit die inrigting se konstante strewe was om godvresende en altyd beter toegeruste Evangeliedienaars vir die kerkdiens te kweek. En die vrug het nie uitgebly nie. Was die strewe egter nie altyd ewe suksesvol nie, dan kan dit nie aan onverskilligheid of beginselversaking gewyt word nie, maar wel aan die feit, dat menslike swakhede ons beste werke altyd aanklewe.

(d) Tóg mag tans, na soveel jare van arbeid, met groot blyúskap melding gemaak word van die heuglike feit, dat die deur ons vaders voorgestelde doel grootliks bereik is. Die Skool het nie ontaard nie. Dit het nie altyd so „klein" gebly nie. Inteendeel, daar was groeikrag, vooruitgang en wasdom van Bó. En in dieselfde mate het dit ook meer diens gelewer en het betekenis vir ons kerklike- en volkslewe alhoemeer toegeneem.

Wat betref die algemeen-wetenskaplike ontwikkeling en teologiese toerusting van studente aan die Skool,- - daarvan kan sonder vrees vir oordrywing gesê word, dat die Skool met reusespronge vooruitgegaan het sinds sy verplasing na Potchefstroom in 1905 en daarna, sinds die inkorporasie van die literariese departement in die Universiteit van Suid-Afrika. Die verskil tussen die oue, nuwe en nuutste opleiding, algemene en teologiese, is baie groot. Gelukkig raak dit nie die prinsipiële, maar net die formele kant van die opleiding. Was universitêre en doktorsgrade voorheen iets ongekends of altans baie seldsaam onder ons teologiese geledere, tans is dit die geval nie meer nie. Nog opvallender is die uitgroeiing van die literariese departement sinds die inlywing van 1921. Hier is die verskil selfs só fenomenaal, dat daar formeel geen vergelyking meer tussen die ou lit. departement en die nuwe P.U.K. vir C.H.O. gemaak kan word nie. Die nuwe het die oue totaal ontgroei! Vir meer besonderhede verwys ek die belangstellende leser na die Jaarboek van genoemde inrigting. En ook hierdie inrigting staan, Gode sy dank, nog op Christelikgelowige grondslag, en bestudeer die wetenskappe by die lig van die Godsopenbaring. Vandaar sy leuse: „In U Lig."

(Sien hoofwet no. 25 van 1921 en wysiging van 1933). 
(e) Oor die betekenis van die dogter, die P.U.K. vir ons kerklike lewe wei ek tans nie uit nie, behoudens één punt, wat hier besondere vermelding verdien, dat die P.U.K. tans die enigste samestellende kollege van die Universiteit van Suid-Afrika is, wat teologie doseer en waardeur die genoemde Universiteit instaat gestel word om B.D., M.Div. en D.D. grade in die teologie te verleen. Dit is 'n prestasie en 'n hoë onderskeiding vir die P.U.K. en 'n eer vir die Gereformeerde Kerk. Maar dit het ook prinsipiële betekenis, vir ons Calvinistiese wêreldbeskouing. ' $n$ ' Betekenis, wat nie altyd onder woorde gebring kan word nie, omdat dit sedelikgeestelik van aard is. Maar, wat tog soos 'n suurdeeg in- en deurwerk op die deeg van ons gesins-, skool- en volkslewe, en wat indirek ons kerklike lewe ten goede kom.

Volgens professor Cachet, was, soos reeds bo vermeld,- die doel met die Skoolstigting tweevoudig: „Aflereerst wilden wij dienaren voor de Kerk vormen; maar tegelijkertijd wenschten wij algemeen nuttig te zijn. Zal de jongeling zijn weg zuiver houden naar Gods Woord, dan moet hij ook leeren om in en door de wetenschap God te dienen. De Bijbel moet grondslag zijn van alle onderwijs en daarom stichtten wij twintig jaar geleden eene school op den Bijbel gegrond, om alzoo voor land en volk nuttig te kunnen zijn, en de waarheid, Gods ook in Zuid-Afrika te handhaven."

(f) En nou, na 'n driekwart eeu word die nageslag geroep om homself rekenskap van sy rentmeesterskap te gee,- of die Skool naamlik aan sy doel beantwoord het. Op die vraag wil ek, saamvattend en afsluitend, as volg antwoord:

1. Die Skool (Kuratorium, Teologiese Senaat, Professore en Studente) het sy Konfessionele Grondslag behou, tot seën vir die Kerk. Dit is 'n blye tyding, waar ons temidde van die „Afval" lewe. .

2. Die Skool het sy oorspronklike Doelstelling getrou en volhardend nagestrewe en dit ook, ondanks teënhede, grootliks bereik.

3. Die Skool het, ondanks 'n baie klein begin, sterk uitgegroei, sowel wat die professore- en studente-tal, as wat sy invloed, invloedsfeer, studiekursusse, biblioteck, fondse, geboue, administrasie ens. betref.

4. Die Skool het deur die pennevrug van sy leerkragte en oudstudẹnte gepresteer, en daardeur vér buite eie kerklike kringe bekendheid en selfs roem verwerf. Direk of indirek tot welsyn van die Gereformeerde Kerk en tot bevordering van ons Calvinistiese wêreld- en lewensbeskouing.

5. Die Skool het „pyle geslyp,"-jong manne gevorm en toegerus vir die veelsydige arbeid van Kerk en Sending; en deur sy invloed, ook vir die C.N.O.-manne, wat die Kerk vir jare lank trou gedien het tot die dag van hulle dood toc. Manne, wat met hulle eggenotes 'n scền vir ons 
gemeentes was en nog is. Wat allesins toegerus is, om die Wag waar te neem by die poort van die Waarheid en van die duurgekoopte Bruidkerk. Manne, deur wie se arbeid die Kerk nie alleen bedien is met Woord, Sakrament en allerlei geestelike versorging nie, maar ook uitgebrei het tot vér oor die grense van die Unie.

- Vergelyk almanakopgawes van, sê die jaar 1890, 1910 en 1940 met $t$ mekaar, en die uitbreiding is opvallend.

6. Op volledigheid maak ek met dié opsomming geen aanspraak nie, ie, -ek wil hiermee slegs ' $n$ aanduiding gee van die feit, dat die Here ciod die eens begonne werk-deur die vaders en moeders van ons Kerk-inderdaad ryklik geseën het. En dat die waarde van ons Teologiese Skool vir ons Kerk moeilik oorskat kan word. Die Skool het die Here, en daardeur ook sy Kerk trou gedien gedurende al die jare van sy bestaan. Dáárvoor, namens die h.h. Kuratore die hartlike dank aan die broeders professore, studente en al ons gemeentes! Maar, bo alles aan Hóm, die Gewer van alle dinge!

En nou ... die Toekoms? Laat ons voortgaan en voortbou; getrou wees en bly aan die Kerk, aan ons Volk en aan die Here onse God, solank as Hy ons spaar! Dán, geen nood!

Bloemfontein.

I. D. KRÜGER.

September 1944. 